\title{
Does the APACHE II score predict performance of activities of daily living in patients discharged from a weaning center?
}

\author{
Anna Rojek-Jarmuła ${ }^{1,2}$, Rainer Hombach ${ }^{1}$, tukasz J. Krzych ${ }^{3}$ \\ ${ }^{1}$ Weaning Station, Marienhaus Klinikum Eifel, Neuerburg, Germany \\ ${ }^{2}$ Department of Anesthesiology and Intensive Care, Marienhaus Klinikum Eifel St. Elizabeth, Gerolstein, Germany \\ ${ }^{3}$ Department of Anesthesiology and Intensive Care, School of Medicine, Medical University of Silesia, Katowice, Poland
}

Kardiochirurgia i Torakochirurgia Polska 2016; 13 (4): 353-358

\begin{abstract}
Introduction: Data regarding the functional status of patients after prolonged mechanical ventilation are scarce, and little is known about its clinical predictors.

Aim: To investigate whether the Acute Physiology and Chronic Health Evaluation (APACHE) II score on admission may predict performance in activities of daily living on discharge from a weaning center.

Material and methods: All consecutive patients admitted between January 1, 2012 and December 31, 2013 were enrolled $(n=130)$. During this period, 15 subjects died, and 115 were successfully discharged (34 women; 81 men). APACHE II was calculated based on the worst values taken during the first 24 hours after admission. On discharge, the Barthel Index (BI) and its extended version, the Early Rehabilitation Barthel Index (ERBI), were assessed.

Results: Median BI was 20 points (IQR 5; 40), and ERBI was 20 points $(-50 ; 40)$. There was no correlation between APACHE II and either $\mathrm{BI}(R=-0.07 ; p=0.47)$ or $\mathrm{ERBI}(R=-0.07 ; p=0.44)$. APACHE II predicted the need for assistance with bathing (AUROC $=0.833 ; p<0.001)$, grooming (AUROC $=0.823 ; p<0.001)$, toilet use (AUROC $=0.887 ; p<0.001)$, and urination (AUROC = 0.658 ; $p=0.04)$. APACHE II had no impact on any ERBI items associated with ventilator weaning, including the need of further mechanical ventilation (AUROC $=0.534 ; p=0.65$ ) or tracheostomy (AUROC $=0.544 ; p=0.42$ ).

Conclusions: Although APACHE II cannot predict the overall functional status in patients discharged from a weaning center, it helps identify subjects who will need support with bathing, grooming, and toilet use. The APACHE II score is inadequate to predict performance in activities associated with further respiratory support.
\end{abstract}

Key words: prolonged mechanical ventilation, weaning, APACHE, functional status, Barthel Index.

\section{Streszczenie}

Wstęp: Istnieją ograniczone dane dotyczące stanu funkcjonalnego chorych przewlekle wentylowanych mechanicznie i predyktorów klinicznych tego stanu.

Cel: Ocena, czy punktacja w skali APACHE II przy przyjęciu na oddział, na którym chorzy są odzwyczajani od respiratora, przewiduje ich funkcjonowanie w zakresie czynności życia codziennego przy wypisie.

Materiat i metody: Do badania włączono chorych $(n=130)$ kolejno leczonych od 1 stycznia 2012 do 31 grudnia 2013 roku. W tym czasie zmarło 15 chorych, a 115 zostało wypisanych (34 kobiety, 81 mężczyzn). Punktację w skali APACHE II obliczono na podstawie najgorszych wartości uzyskanych podczas 24 godzin od przyjęcia. Przy wypisie z oddziału obliczono wartość punktacji w skali Barthel (BI) oraz jej rozszerzonej wersji: Early Rehabilitation Barthel Index (ERBI).

Wyniki: Mediana BI wynosiła 20 (IQR 5; 40) pkt, a ERBI 20 $(-50 ; 40)$ pkt. Nie stwierdzono zależności pomiędzy punktacją w skali APACHE II a BI $(R=-0,07 ; p=0,47)$ oraz ERBI $(R=-0,07$; $p=0,44)$. Skala APACHE II pozwalała przewidzieć konieczność pomocy w utrzymaniu higieny osobistej (AUROC $=0,833$; $p<0,001$ ), ubieraniu (AUROC $=0,823 ; p<0,001$ ), korzystaniu $z$ toalety $(A \cup R O C=0,887 ; p<0,001)$ oraz kontrolowaniu oddawania moczu (AUROC $=0,658 ; p=0,04$ ). Nie miała natomiast wpływu na parametry związane $z$ odzwyczajeniem od respiratora, $w$ tym konieczność dalszej wentylacji (AUROC $=0,534$; $p=0,65)$ i utrzymanie tracheostomii (AUROC $=0,544 ; p=0,42$ ). Wnioski: Choć skala APACHE II nie pozwala przewidzieć ogólnego funkcjonowania chorych przewlekle wentylowanych odzwyczajanych od respiratora, jest cennym narzędziem do predykcji konieczności pomocy w utrzymaniu higieny osobistej, ubieraniu i korzystaniu z toalety. APACHE II nie pozwala przewidzieć funkcjonowania w zakresie czynności związanych z koniecznością dalszego wsparcia oddechowego.

Słowa kluczowe: przewlekła wentylacja mechaniczna, odzwyczajanie od respiratora, APACHE, stan funkcjonalny, skala Barthel.

Address for correspondence: Łukasz J. Krzych MD, Department of Anesthesiology and Intensive Care, School of Medicine, Medical University of Silesia, 9 M. Curie-Skłodowskiej St, 41-800 Zabrze, Poland, phone/fax: +48 32273 27 31, e-mail: l.krzych@wp.pl

Received: 3.08.2016, accepted: 9.09.2016. 


\section{Introduction}

Patients requiring prolonged mechanical ventilation (PMV) pose a considerable medical, social, and economic burden for the healthcare system [1, 2]. The number of subjects being mechanically ventilated is predicted to increase, particularly among the elderly and patients with comorbidities [3]. Successful weaning from mechanical ventilation remains challenging from the clinical and organizational point of view $[1,2]$. Therefore, the concept of specialized weaning centers has received increasing interest.

Being discharged from this type of unit is the first step of further rehabilitation $[1,2]$. The discharge destination is influenced by a broad spectrum of health-related and social factors. Only subjects with adequate functional status and sufficient family support can safely return to a home environment. Those with impaired performance in activities of daily living or without satisfactory help of caregivers are usually transferred to rehabilitation centers or extended care facilities $[1,2]$. The rehabilitation process is long-lasting, time-consuming, and multidisciplinary $[4,5]$. Basically, it includes daily physical therapy and respiratory muscle strength training to overcome the sequelae of critical illness, malnutrition, and the side effects of artificial ventilation $[4,5]$.

Data regarding the functional status of patients after PMV are limited, and little is known about its clinical predictors [6-9]. Moreover, there is no widely accepted standard measure of functional independence and the need for assistance with mobility and self-care in this unique group of patients [10, 11]. Finally, no attempts have been made to assess the validity of the acknowledged intensive care unit (ICU) scoring systems in predicting functional status on discharge.

\section{Aim}

Therefore, we sought to investigate whether the Acute Physiology and Chronic Health Evaluation (APACHE) II score

Tab. I. Baseline characteristics of the study group

\begin{tabular}{lc} 
Variable & Median (IQR) or percent \\
Men/women & $70.4 / 29.6$ \\
\hline Age [years] & $72(62-77)$ \\
\hline Postoperative respiratory failure & 59.1 \\
\hline Chronic obstructive pulmonary disease & 45.2 \\
\hline Acute respiratory distress syndrome & 30.4 \\
\hline Pulmonary embolism & 4.3 \\
\hline Pneumonia & 98.3 \\
\hline Anemia & 62.2 \\
\hline Any paresis or paralysis & 32.2 \\
\hline Critical illness polyneuropathy & 98.3 \\
\hline Phrenic nerve palsy & 10.4 \\
\hline Neoplastic disease & 13.0 \\
\hline Post-cardiac arrest syndrome & 13.0 \\
\hline Dysphagia & 100.0 \\
\hline
\end{tabular}

on admission may predict performance in activities of daily living in patients discharged from weaning centers.

\section{Material and methods}

In this retrospective analysis, we enrolled 130 consecutive patients admitted to a weaning center (Weaning Station Neuerburg) between January 1, 2012 and December 31, 2013. During this period, 15 (11.5\%) subjects died, while 115 (88.5\%) patients were successfully discharged.

The indications for admission were based on the guidelines of the German Respiratory Society [12]. The treatment strategy and weaning procedures were implemented according to the nationwide recommendations [12], with adjustment to local standards. More details regarding this issue have been published previously [13].

Data covering demographics, comorbid conditions, and clinical variables were retrieved from medical records. Clinical and laboratory data were recorded on the first day of admission. The APACHE II score was calculated [14] based on the worst values taken during the first $24 \mathrm{~h}$ after admission. To eliminate the possible confounding effect of analgesic and sedative agents on the scoring, we excluded the Glasgow Coma Scale (GCS) (baseline median RASS = -1 points; IQR -2 to +1 ) [15]. Patient confidentiality was ensured as the dataset was fully anonymized. The Ethics Committee of the Medical University of Silesia approved the study with a waiver of consent because the project was non-interventional.

The outcome measures included performance in activities of daily living on discharge (the overall status and subsequent items). We calculated the Barthel Index (BI) and its extended version, the Early Rehabilitation Barthel Index (ERBI) [16].

\section{Statistical analysis}

Statistical analysis was performed using MedCalc Statistical Software version 14.8.1 (MedCalc Software bvba, Ostend, Belgium). Continuous variables are expressed as medians and interquartile ranges (IQR, i.e. $25^{\text {th }} ; 75^{\text {th }}$ percentile). Qualitative variables are expressed as percentages. Intergroup differences in quantitative variables were assessed using the Mann-Whitney $U$-test after the type of distribution was verified using the Shapiro-Wilk test. Correlation was determined using Spearman's rank coefficient. The area under the receiver operating characteristic curve (AUROC) was calculated to determine the ability of the APACHE II score to predict performance in activities of daily living as independent variables. A $p$-value $<0.05$ was considered significant.

\section{Results}

This final analysis covered 115 survivors (34 women and 81 men) discharged from a weaning center. The subjects' baseline characteristics, including major health conditions with serious impact on functional status, are shown in Table I. The median APACHE II score (excluding the GCS) was 11 points $(8.25 ; 14)$. 
The median stay in a weaning unit was 27 days (20; 36). Regarding discharge disposition, the majority of the patients $(53.9 \%)$ were transferred to a rehabilitation center (Tab. II). The median BI was 20 points $(5 ; 40)$, and the ERBI was 20 points $(-50 ; 40)$ (Fig. 1$)$. Both the $\mathrm{BI}(p=0.6)$ and the $\mathrm{ERBI}(p=0.4)$ were comparable between men and women.

There was no correlation between the APACHE II score and either the $\mathrm{BI}(R=-0.07 ; p=0.47)$ or the $\mathrm{ERBI}(\mathrm{R}=-0.07$; $p=0.44$ ) (Fig. 2). However, we found statistically significant but weak correlations between the APACHE II score and the scoring of two $\mathrm{BI}$ items: bathing $(R=-0.21 ; p=0.02)$ and transferring from bed to chair $(R=-0.19 ; p=0.04)$ (Tab. III).

The patients requiring any assistance with bathing $(p=0.02)$, grooming $(p=0.04)$, urination $(p=0.04)$, and toilet use $(p=0.02)$ had statistically significantly higher APACHE II scores (Tab. IV). Moreover, the APACHE II score predicted with good diagnostic accuracy the need for assistance with bathing (AUROC $=0.833 ; p<0.001$; cut-off of 9 points), grooming (AUROC $=0.823 ; p<0.001$; cut-off of 9 points), and toilet use (AUROC $=0.887 ; p<0.001$; cutoff of 9 points); it also predicted with moderate accuracy the need for assistance with urination (AUROC $=0.658$; $p=0.04$; cut-off of 10 points). Interestingly, the APACHE II
Tab. II. Weaning center discharge destinations

\begin{tabular}{lc} 
Discharge destination & Percent \\
Rehabilitation unit & 53.9 \\
\hline Geriatric unit & 13.9 \\
\hline Home & 11.3 \\
\hline Surgical unit & 7.8 \\
\hline Internal medicine unit & 7.0 \\
\hline Rest home & 5.2 \\
\hline Neurological unit & 0.9
\end{tabular}

score had no impact on any items added to the ERBI in comparison to the $\mathrm{BI}$.

\section{Discussion}

Prolonged weaning requires a holistic approach [17]. The physical health of PMV subjects treated in respiratory intensive care units is markedly worsened in comparison to the general population [18], and discharge destinations are influenced by a variety of patient-related factors. Patients with acceptable functional status return home directly or after complex rehabilitation programs. Those with poor

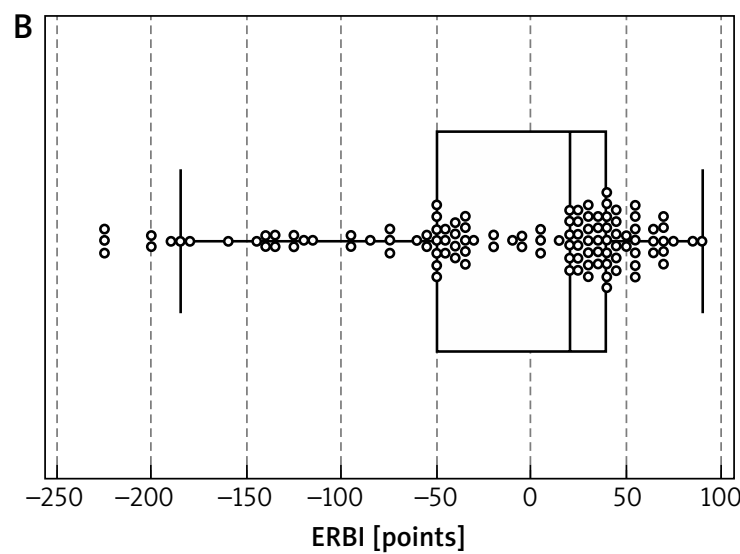

Fig. 1. Barthel Index (BI; A) and Early Rehabilitation Barthel Index (ERBI; B)
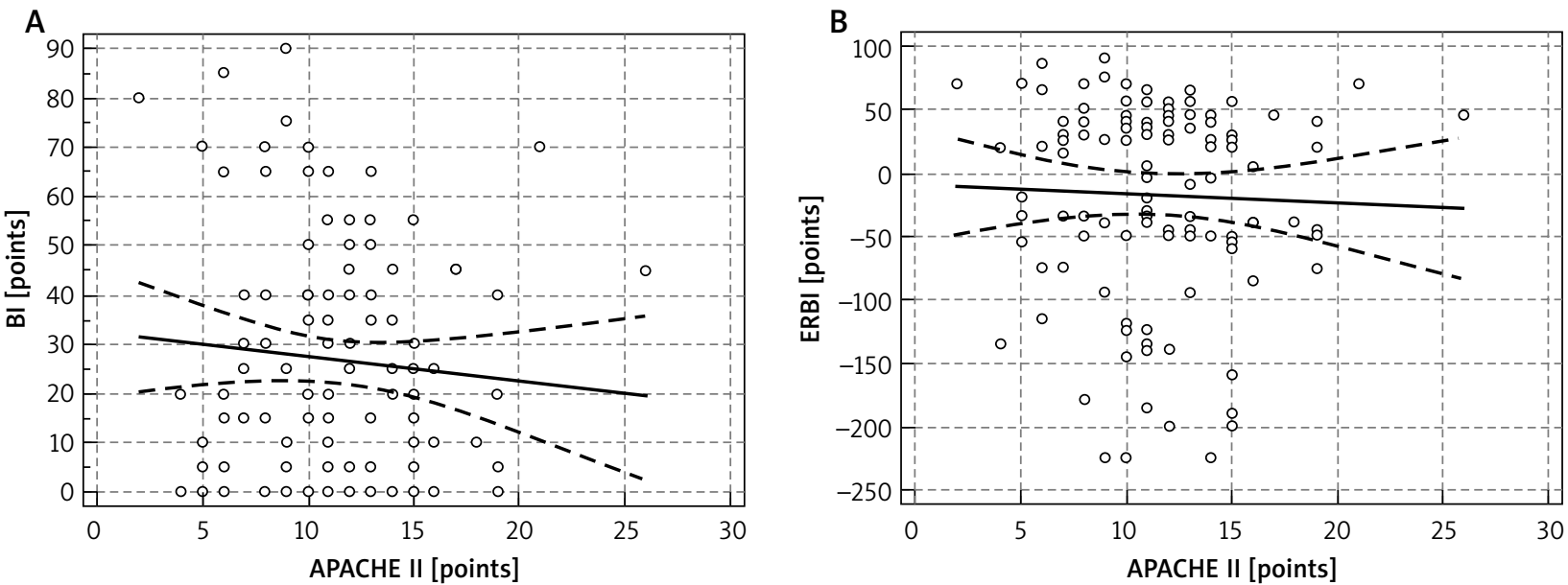

Fig. 2. Correlation between the APACHE II score on admission and the Barthel Index (BI; A) and Early Rehabilitation Barthel Index (ERBI; B) on discharge 
Tab. III. Correlations between the APACHE II score and the items of the Barthel Index (BI)/Early Rehabilitation Barthel Index (ERBI)

\begin{tabular}{ll} 
BI/ERBI item & $\begin{array}{c}\text { Spearman's rank correlation } \\
\text { coefficient (' } p \text { ') }\end{array}$ \\
\hline Feeding & $-0.09(p=0.36)$ \\
\hline Bathing & $-0.21(p=0.02)$ \\
\hline Grooming & $-0.05(p=0.61)$ \\
\hline Dressing & $-0.06(p=0.52)$ \\
\hline Bowels & $-0.02(p=0.83)$ \\
\hline Bladder & $-0.01(p=0.88)$ \\
\hline Toilet use & $-0.01(p=0.88)$ \\
\hline Transfer (bed to chair and back) & $-0.19(p=0.04)$ \\
\hline Mobility (on level surfaces) & $-0.03(p=0.73)$ \\
\hline Stairs & $-0.18(p=0.06)$ \\
\hline Monitoring & $-0.11(p=0.25)$ \\
\hline Orientation & $0.14(p=0.13)$ \\
\hline Dysphagia & $0.06(p=0.56)$ \\
\hline Communication & $0.17(p=0.06)$ \\
\hline Behavior & $0.06(p=0.51)$ \\
\hline Tracheostomy & $0.07(p=0.43)$ \\
\hline Ventilation & $-0.05(p=0.62)$ \\
\hline
\end{tabular}

functioning usually require additional care in long-term nursing facilities. Functional status is often recognized as the best predictor of outcome in patients liberated from mechanical ventilation $[15,19]$. Therefore, we explored this interesting issue in terms of the association between baseline disease severity according to the APACHE II and performance in activities of daily living on discharge according to the $\mathrm{BI} / \mathrm{ERBI}$. To our knowledge, this is the first study to investigate this problem. Hence, it is difficult to compare our findings with others. Only Montagnani et al. [7] found that the Functional Independence Measure in ventilatordependent patients in a weaning unit correlated negatively with the APACHE II score $(R=-0.286)$.

No more than half of patients in weaning centers receive adequate physical therapy with regard to its frequency and intensity [20-22]. Nevertheless, it was confirmed that appropriate rehabilitation during hospital stay increases the BI approximately twofold and the weaning success by about $50 \%$ [21], while early mobilization is a positive independent factor contributing to being discharged home [23]. Ceriana et al. [24] also demonstrated that, after rehabilitation during respiratory ICU stay, the mean Dependence Nursing Scale score improved, decreasing from 23 to 12 points.

Using the Zubrod score, Scheinhorn et al. [25] revealed that $37.8 \%$ of the weaned subjects were bedridden for at least $50 \%$ of the time (with limited self-care), while $31.2 \%$ were fully bedridden. Overall poor functional status (i.e., Zubrod 3-4) was observed in $69 \%$ of patients on discharge, but it improved significantly by about $40 \%$ in survivors during a 1-year follow-up [25]. This is in line with the results of Bigatello et al. [26], who revealed that, in a cohort of mechanically ventilated patients, the level of physical activity of daily living increased progressively from $24 \pm 6$ points (on a 100-point scale) at hospital discharge, through $54 \pm 12$ points at 3 months, to $64 \pm 22$ points at 6 months. Combes et al. [27] also showed that, in a 3-year follow-up, 99\% of PMV survivors were functionally independent and living at home. However, one should bear in mind that post-discharge 3-year mortality often exceeds 50\% [28].

In a group of patients requiring PMV after cardiac surgery, Engoren et al. [29] found that $16 \%$ of the patients were limited in their activities of daily living (eating, dressing, bathing), while $60 \%$ had limitations of moderate activity. Only $36 \%$ could climb stairs or walk uphill without limitations, and $54 \%$ could walk the length of one block [29]. It seems interesting that bathing has been recognized as a central care activity for PMV patients in a weaning unit, because it involves the overall patient's health condition and activity tolerance [30]. Other activities related to personal care and hygiene have also been highly valued by patients and caregivers [30]. Thus, our findings related to the association between the APACHE II score and bathing, grooming, and toilet use deserve special attention. There are also some data indicating that women have a better functional response when admitted to the ICU, spending less time ventilated and performing active exercises earlier [31], but we did not find any intergender differences in our study group.

Neuropsychiatric complications and abnormalities also compromise the outcome and reduce progress in rehabilitation. Weaning from PMV is associated with mental discomfort, with the development of post-traumatic disorders in $12 \%$ of patients 3 months after liberation from mechanical ventilation [32]. In a study by Rose et al., thirst, lack of control, and noise were the most frequently recalled stressful situations from interdisciplinary ICUs, while medical procedures, night awakening, and inability to sleep were the most frequently recalled experiences from weaning centers [33]. Moreover, about 30\% of the weaned patients experience neurological deficits, and $40 \%$ of the remaining group are diagnosed with depressive disorders [34].

To overcome the abovementioned drawbacks, several rehabilitation protocols for critical care nurses, nursing assistants, physical therapists, language pathologists, and psychologists have been suggested so far $[35,36]$. When implemented early, they are feasible and safe; they do not increase costs and are associated with improved outcomes in survivors [36].

\section{Study limitations}

Firstly, each center has its own specific patient characteristics, admission and discharge criteria, weaning protocols, as well as diagnostic and therapeutic procedures. This limits the application of our findings in a broader context. On the one hand, direct comparisons of the results between units must, therefore, be limited and cautious. On the other hand, weakness, skeletal and inspiratory muscle dysfunction, swallowing problems, and the urgent need for total body (and mental) rehabilitation are nearly universal 
Tab. IV. APACHE II score by items of Barthel Index/Early Rehabilitation Barthel Index

\begin{tabular}{|c|c|c|c|c|}
\hline \multirow[t]{2}{*}{ Item } & \multirow{2}{*}{\multicolumn{2}{|c|}{$\begin{array}{l}\text { Any assistance required } \\
\text { (no. of patients) }\end{array}$}} & \multicolumn{2}{|c|}{ APACHE II score } \\
\hline & & & Median points (IQR) & AUROC; $95 \% \mathrm{Cl}\left({ }^{\prime} p^{\prime}\right)$ \\
\hline \multirow{2}{*}{ Feeding } & Yes & 74 & $11(9 ; 14)$ & \multirow{2}{*}{$\begin{array}{c}0.501 ; 0.406-0.596 \\
(p=0.98)\end{array}$} \\
\hline & No & 41 & $12(8 ; 13)$ & \\
\hline \multirow{2}{*}{ Bathing } & Yes & 4 & $11(9 ; 14)^{\star}$ & \multirow{2}{*}{$\begin{array}{c}0.833 ; 0.752-0.896 \\
(p<0.001)\end{array}$} \\
\hline & No & 111 & $8(4.5 ; 9)$ & \\
\hline \multirow{2}{*}{ Grooming } & Yes & 113 & $11(8.75 ; 14)^{\star}$ & \multirow{2}{*}{$\begin{array}{c}0.823 ; 0.741-0.888 \\
(p<0.001)\end{array}$} \\
\hline & No & 2 & $7.5(6 ; 9)$ & \\
\hline \multirow{2}{*}{ Dressing } & Yes & 112 & $11(8.5 ; 14)$ & \multirow{2}{*}{$\begin{array}{c}0.552 ; 0.457-0.645 \\
(p=0.79)\end{array}$} \\
\hline & No & 3 & $9(8.25 ; 13.5)$ & \\
\hline \multirow{2}{*}{ Bowels } & Yes & 94 & $11(9 ; 14)$ & \multirow{2}{*}{$\begin{array}{c}0.577 ; 0.482-0.669 \\
\quad(p=0.28)\end{array}$} \\
\hline & No & 21 & $10(7.75 ; 13)$ & \\
\hline \multirow{2}{*}{ Bladder } & Yes & 100 & $11(9 ; 14)^{*}$ & \multirow{2}{*}{$\begin{array}{c}0.658 ; 0.563-0.744 \\
(p=0.04)\end{array}$} \\
\hline & No & 15 & $9(6.5 ; 11.75)$ & \\
\hline \multirow{2}{*}{ Toilet use } & Yes & 112 & $11(9 ; 14)^{\star}$ & \multirow{2}{*}{$\begin{array}{c}0.887 ; 0.814-0.938 \\
(p<0.001)\end{array}$} \\
\hline & No & 3 & $6(3 ; 8.25)$ & \\
\hline \multirow{2}{*}{ Transfer (bed to chair and back) } & Yes & 114 & $11(8 ; 14)$ & \multirow{2}{*}{ NA } \\
\hline & No & 1 & $9(9 ; 9)$ & \\
\hline \multirow{2}{*}{ Mobility (on level surfaces) } & Yes & 110 & $11(9 ; 14)$ & \multirow{2}{*}{$\begin{array}{c}0.620 ; 0.525-0.709 \\
(p=0.45)\end{array}$} \\
\hline & No & 5 & $9(7.5 ; 12.75)$ & \\
\hline \multirow{2}{*}{ Stairs } & Yes & 115 & $11(8.25 ; 14)$ & \multirow{2}{*}{ NA } \\
\hline & No & 0 & - & \\
\hline \multirow{2}{*}{ Intensive care supervision } & Yes & 16 & $12(10 ; 15)$ & \multirow{2}{*}{$\begin{array}{c}0.586 ; 0.490-0.677 \\
(p=0.31)\end{array}$} \\
\hline & No & 99 & $11(8 ; 13)$ & \\
\hline \multirow{2}{*}{ Confused patient in need of supervision } & Yes & 11 & $10(6.75 ; 11.75)$ & \multirow{2}{*}{$\begin{array}{c}0.639 ; 0.544-0.726 \\
(p=0.11)\end{array}$} \\
\hline & No & 104 & $11(8.5 ; 14)$ & \\
\hline \multirow{2}{*}{ Dysphagia } & Yes & 33 & $11(8.75 ; 14)$ & \multirow{2}{*}{$\begin{array}{c}0.535 ; 0.440-0.628 \\
(p=0.56)\end{array}$} \\
\hline & No & 82 & $11(8 ; 14)$ & \\
\hline Severe imnairment of communication & Yes & 18 & $10(6 ; 11)$ & $0.630 ; 0.535-0.718$ \\
\hline 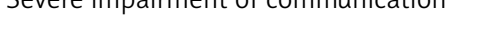 & No & 97 & $11(8.75 ; 14)$ & $(p=0.06)$ \\
\hline Rehavingal dicturbances & Yes & 10 & $10(9 ; 12)$ & $0.557 ; 0.461-0.649$ \\
\hline Defiavioral uisturdanices & No & 105 & $11(8 ; 14)$ & $(p=0.53)$ \\
\hline Tracheoctomv tuhe manarement & Yes & 45 & $11(9.5 ; 14)$ & $0.544 ; 0.448-0.637$ \\
\hline - & No & 70 & $11(8 ; 13.75)$ & $(p=0.42)$ \\
\hline Mechanical ventilation & Yes & 13 & $11(10 ; 14.25)$ & $0.534 ; 0.439-0.628$ \\
\hline 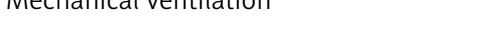 & No & 102 & $11(8 ; 14)$ & $(p=0.65)$ \\
\hline
\end{tabular}

NA - not applicable; ${ }^{*} p<0.05$.

in all weaned patients, regardless of the abovementioned differences. Secondly, the retrospective nature of our study means that some data, particularly those related to baseline functional status, were unobtainable. Thirdly, we lack data concerning long-term survival and post-discharge performance in activities of daily living. However, we believe that these shortcomings have only a minor impact on the overall value of the study.

\section{Conclusions}

Although the APACHE II score cannot predict the overall functional status in patients on discharge from a weaning center, it helps identify subjects with the need for support with bathing, grooming, and toilet use. Unfortunately, the APACHE II score is inadequate in predicting performance in items particularly associated with further respiratory support. 


\section{Disclosure}

Authors report no conflict of interest.

\section{References}

1. Navalesi P, Frigerio P, Patzlaff A, Häußermann S, Henseke P, Kubitschek M. Prolonged weaning: from the intensive care unit to home. Rev Port Pneumol 2014; 20: 264-272.

2. Ambrosino N, Gabbrielli L. The difficult-to-wean patient. Expert Rev Respir Med 2010; 4: 685-692.

3. Zilberberg MD, de Wit M, Shorr AF. Accuracy of previous estimates for adult prolonged acute mechanical ventilation volume in 2020: update using 20002008 data. Crit Care Med 2012; 40: 18-20.

4. Ntoumenopoulos $G$. Rehabilitation during mechanical ventilation: review of the recent literature. Intensive Crit Care Nurs 2015; 31: 125-132.

5. Mendez-Tellez PA, Needham DM. Early physical rehabilitation in the ICU and ventilator liberation. Respir Care 2012; 57: 1663-1669.

6. Ponfick M, Wiederer R, Bösl K, Neumann G, Lüdemann-Podubecka J, Gdynia HJ, Nowak DA. The influence of weaning duration on rehabilitative outcome in early neurological rehabilitation. NeuroRehabilitation 2014; 34: 493-498.

7. Montagnani G, Vagheggini G, Panait Vlad E, Berrighi D, Pantani L, Ambrosino N. Use of the functional independence measure in people for whom weaning from mechanical ventilation is difficult. Phys Ther 2011; 91: 1109-1115.

8. Garnacho-Montero J, Amaya-Villar R, García-Garmendía JL, Madrazo-Osuna J, Ortiz-Leyba C. Effect of critical illness polyneuropathy on the withdrawal from mechanical ventilation and the length of stay in septic patients. Crit Care Med 2005; 33: 349-354.

9. Rose L, Fraser IM. Patient characteristics and outcomes of a provincial prolonged-ventilation weaning centre: a retrospective cohort study. Can Respir J 2012; 19: 216-220.

10. White DK, Wilson JC, Keysor JJ. Measures of adult general functional status: SF-36 Physical Functioning Subscale (PF-10), Health Assessment Questionnaire (HAQ), Modified Health Assessment Questionnaire (MHAQ), Katz Index of Independence in activities of daily living, Functional Independence Measure (FIM), and Osteoarthritis-Function-Computer Adaptive Test (OAFunction-CAT). Arthritis Care Res (Hoboken) 2011; 63 (Suppl 11): S297-S307.

11. Katz PP; the Association of Rheumatology Health Professionals Outcomes Measures Task Force. Measures of adult general functional status. Arthritis Rheum 2003; 49 (5 Suppl): S15-S27.

12. Schönhofer B, Geiseler J, Dellweg D, Moerer O, Barchfeld T, Fuchs H, Karg O, Rosseau S, Sitter H, Weber-Carstens S, Westhoff M, Windisch W. Prolonged weaning: S2k-guideline published by the German Respiratory Society. Pneumologie 2014; 68: 19-75.

13. Rojek-Jarmuła A, Hombach R, Gierek D, Krzych ŁJ. A single-centre seven-year experience with mechanical ventilation weaning. Anaesthesiol Intensive Ther 2015; 47: 204-209.

14. Knaus WA, Draper EA, Wagner DP, Zimmerman JE. APACHE II: a severity of disease classification system. Crit Care Med 1985; 13: 818-829.

15. Barchfeld T, Dellweg D, Böckling S, Conze S, Kloske K, Schürholz G, Figge M, Köhler D. Weaning from long-term mechanical ventilation: data of a single weaning center from 2007 to 2011. Dtsch Med Wochenschr 2014; 139: 527-533.

16. Rollnik JD. The Early Rehabilitation Barthel Index (ERBI). Rehabilitation (Stuttg) 2011; 50: 408-411.

17. Henneman E, Dracup K, Ganz T, Molayeme O, Cooper CB. Using a collaborative weaning plan to decrease duration of mechanical ventilation and length of stay in the intensive care unit for patients receiving long-term ventilation. Am J Crit Care 2002; 11: 132-140.
18. Euteneuer S, Windisch W, Suchi S, Köhler D, Jones PW, Schönhofer B. Health-related quality of life in patients with chronic respiratory failure after long-term mechanical ventilation. Respir Med 2006; 100: 477-486.

19. Spicher JE, White DP. Outcome and function following prolonged mechanical ventilation. Arch Intern Med 1987; 147: 421-425.

20. Rose L, Fowler RA, Fan E, Fraser I, Leasa D, Mawdsley C, Pedersen C, Rubenfeld G; CANUVENT group. Prolonged mechanical ventilation in Canadian intensive care units: a national survey. J Crit Care 2015; 30: 25-31.

21. Yang PH, Wang CS, Wang YC, Yang CJ, Hung JY, Hwang JJ, Wang TH, Chuang IC, Huang MS. Outcome of physical therapy intervention on ventilator weaning and functional status. Kaohsiung J Med Sci 2010; 26: 366-372.

22. Jolley SE, Caldwell E, Hough CL. Factors associated with receipt of physical therapy consultation in patients requiring prolonged mechanical ventilation. Dimens Crit Care Nurs 2014; 33: 160-167.

23. Ota H, Kawai H, Sato M, Ito K, Fujishima S, Suzuki H. Effect of early mobilization on discharge disposition of mechanically ventilated patients. J Phys Ther Sci 2015; 27: 859-864.

24. Ceriana P, Delmastro M, Rampulla C, Nava S. Demographics and clinical outcomes of patients admitted to a respiratory intensive care unit located in a rehabilitation center. Respir Care 2003; 48: 670-676.

25. Scheinhorn DJ, Hassenpflug MS, Votto JJ, Chao DC, Epstein SK, Doig GS, Knight EB, Petrak RA; Ventilation Outcomes Study Group. Post-ICU mechanical ventilation at 23 long-term care hospitals: a multicenter outcomes study. Chest 2007; 131: 85-93.

26. Bigatello LM, Stelfox HT, Berra L, Schmidt U, Gettings EM. Outcome of patients undergoing prolonged mechanical ventilation after critical illness. Crit Care Med 2007; 35: 2491-2497.

27. Combes A, Costa MA, Trouillet JL, Baudot J, Mokhtari M, Gibert C, Chastre J. Morbidity, mortality, and quality-of-life outcomes of patients requiring >or=14 days of mechanical ventilation. Crit Care Med 2003; 31: 1373-1381.

28. Schönhofer B, Euteneuer S, Nava S, Suchi S, Köhler D. Survival of mechanically ventilated patients admitted to a specialised weaning centre. Intensive Care Med 2002; 28: 908-916.

29. Engoren M, Buderer NF, Zacharias A. Long-term survival and health status after prolonged mechanical ventilation after cardiac surgery. Crit Care Med 2000; 28: 2742-2749.

30. Happ MB, Tate JA, Swigart VA, DiVirgilio-Thomas D, Hoffman LA. Wash and wean: bathing patients undergoing weaning trials during prolonged mechanical ventilation. Heart Lung 2010; 39 (6 Suppl): S47-S56.

31. Daniel CR, Alessandra de Matos C, Barbosa de Meneses J, Bucoski SC, Fréz AR, Mora CT, Ruaro JA. Mechanical ventilation and mobilization: comparison between genders. J Phys Ther Sci 2015; 27: 1067-1070.

32. Jubran A, Lawm G, Duffner LA, Collins EG, Lanuza DM, Hoffman LA, Tobin MJ. Post-traumatic stress disorder after weaning from prolonged mechanical ventilation. Intensive Care Med 2010; 36: 2030-2037.

33. Rose L, Nonoyama M, Rezaie S, Fraser I. Psychological wellbeing, health related quality of life and memories of intensive care and a specialised weaning centre reported by survivors of prolonged mechanical ventilation. Intensive Crit Care Nurs 2014; 30: 145-151.

34. Jubran A, Lawm G, Kelly J, Duffner LA, Gungor G, Collins EG, Lanuza DM, Hoffman LA, Tobin MJ. Depressive disorders during weaning from prolonged mechanical ventilation. Intensive Care Med 2010; 36: 828-835.

35. Scheinhorn DJ, Chao DC, Stearn-Hassenpflug M, Wallace WA. Outcomes in post-ICU mechanical ventilation: a therapist-implemented weaning protocol. Chest 2001; 119: 236-242.

36. Morris PE, Goad A, Thompson C, Taylor K, Harry B, Passmore L, Ross A, Anderson L, Baker S, Sanchez M, Penley L, Howard A, Dixon L, Leach S, Small R, Hite RD, Haponik E. Early intensive care unit mobility therapy in the treatment of acute respiratory failure. Crit Care Med 2008; 36: 2238-2243. 